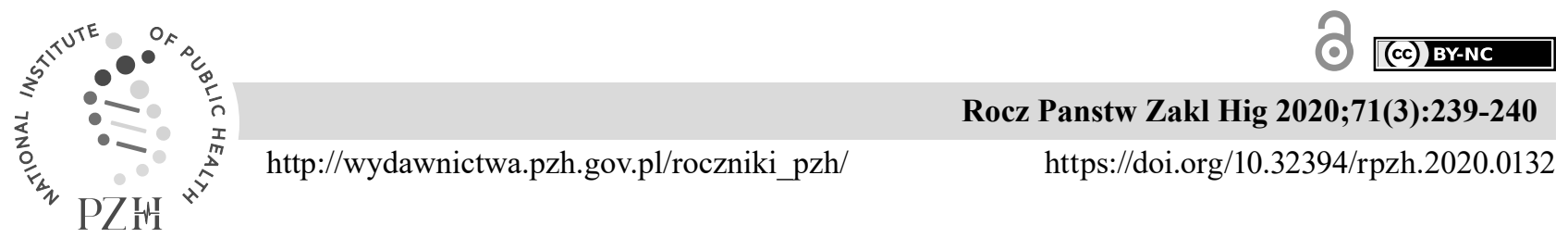

\title{
In Memoriam: Professor Andrzej Wojtczak, MD (1933 - 2020)
}

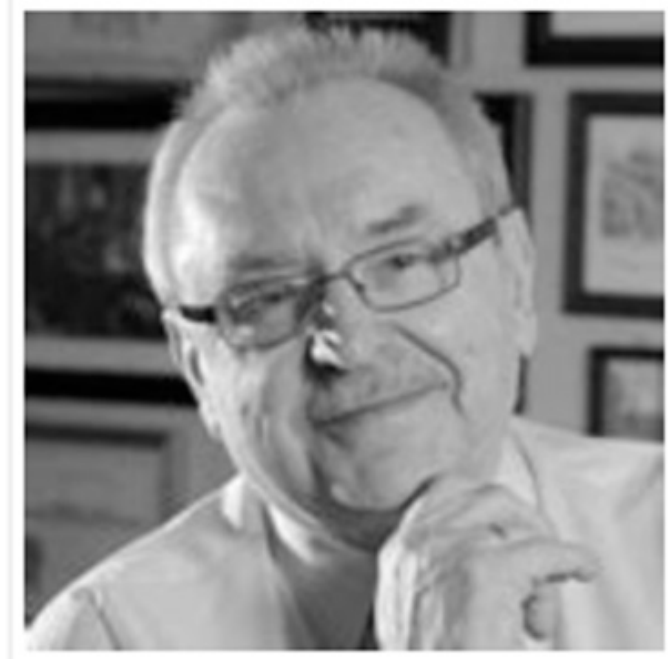

Prof. dr hab. med. Andrzej Wojtczak

(1933-2020)

With sincere sadness and regret we bid farewell to Professor Andrzej Wojtczak, a man who like no one else was able to reconcile and unit in common work, even those holding extremely different viewpoints. Being an outstanding physician and clinician he became one of the most influential propagators of public health, both in Poland and worldwide.

By co-chairing the 1989 Round Table negotiations on the Health Sector, he was able to achieve an effective compromise between deeply divergent parties.

Drawing on the attitude of a sincere, positivist-oriented patriotism formed in Poznań and holding high positions of responsibility at the Polish Ministry of Health, he was able to move freely amongst international institutions - at many levels within the World Health Organisation, Public Health Committee of the European Union, Health Committee of the Council of Europe in Strasbourg, as well as in numerous scientific societies.

Everywhere he worked, he left behind many loyal students who are now joined together in a sense of irreparable loss.

Public Health Committee of the Polish Academy of Sciences National Institute of Public Health - National Institute of Hygiene 


\section{In Memoriam: Profesor Andrzej Wojtczak, MD (1933 - 2020)}

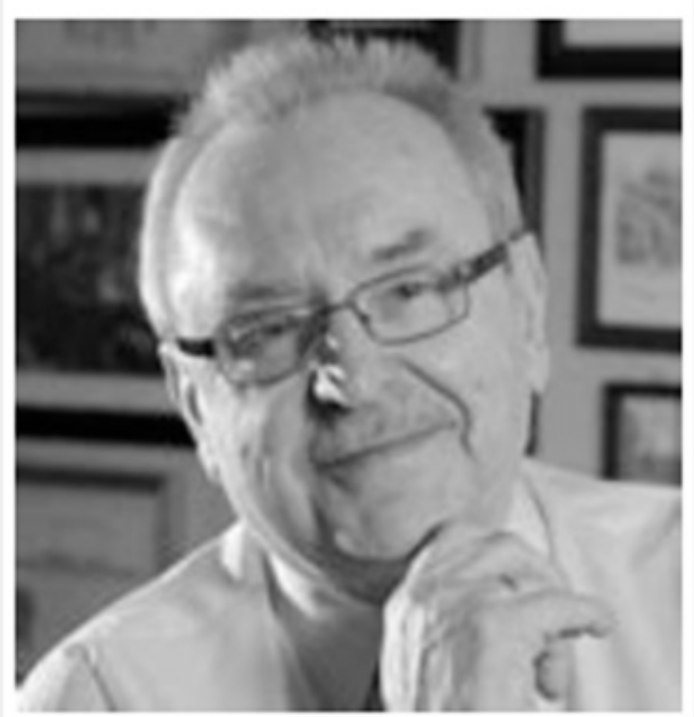

Prof. dr hab. med. Andrzej Wojtczak

(1933-2020)

Ze szczerym smutkiem i żalem żegnamy Profesora Andrzeja Wojtczaka, Człowieka, który jak mało kto potrafił godzić i łączyć we wspólnej pracy przedstawicieli nawet skrajnie różniących się poglądów. Będąc wybitnym lekarzem - klinicystą stał się jednym z najbardziej wpływowych propagatorów zdrowia publicznego w Polsce i na świecie.

Współprzewodnicząc obradom Podzespołu ds. Zdrowia w negocjacjach Okrągłego Stołu w 1989 r. udało mu się doprowadzić do kompromisu głęboko zwaśnione strony.

Czerpiąc z postawy ukształtowanego w Poznaniu, szczerego, pozytywistycznie zorientowanego patriotyzmu i pełniąc odpowiedzialne funkcje w polskim Ministerstwie Zdrowia potrafił swobodnie poruszać się w międzynarodowych instytucjach - na różnych szczeblach Światowej Organizacji Zdrowia, w Komisji Zdrowia Publicznego Unii Europejskiej, w Komitecie ds. Zdrowia Rady Europy w Strassburgu, a także w licznych towarzystwach naukowych.

Wszędzie gdzie pracował, pozostawił po sobie wielu wiernych uczniów, którzy teraz łączą się w poczuciu niepowetowanej straty.

Komitet Zdrowia Publicznego Polskiej Akademii Nauk Narodowy Instytut Zdrowia Publicznego - Państwowy Zakład Higieny 